\title{
Valve surgery in octogenarians: In-hospital and long-term outcomes
}

\author{
Eduardo Bossone MD PhD FESC FACC ${ }^{1}$, Giuseppe Di Benedetto MD², Alessandro Frigiola MD ${ }^{3}$, \\ Giannignazio Luigi Carbone $\mathrm{MD}^{3}$, Antonello Panza $\mathrm{MD}^{2}$, Silvia Cirri $M D^{4}$, Andrea Ballotta $\mathrm{MD}^{3}$, \\ Stefano Messina $M D^{5}$, Saverio Rega $M D^{5}$, Rodolfo Citro $M D^{5}$, Santi Trimarchi $M D^{3}$, Jianming Fang $M D^{6}$, \\ Paolo Righini $\mathrm{MD}^{3}$, Alessandro Distante MD FESC FACC ${ }^{1}$, Kim A Eagle MD FACC ${ }^{6}$, Rajendra H Mehta MD FACC ${ }^{7}$
}

\begin{abstract}
E Bossone, G Di Benedetto, A Frigiola, et al. Valve surgery in octogenarians: In-hospital and long-term outcomes. Can J Cardiol 2006;22(3):223-227.
\end{abstract}

BACKGROUND: Global population aging and greater age-related incidence of ischemic, degenerative and calcific valve disease have led to an increasing number of very elderly patients being referred for valve surgery. However, their preoperative risk factors, and in-hospital and long-term outcomes have not been thoroughly investigated.

METHODS: Three hundred seven consecutive patients 80 years and older ( $60 \%$ female; mean age $83 \pm 2.4$ years) attending three major Italian cardiac centres to undergo valve surgery were evaluated. Seventy-nine patients underwent mitral valve surgery (isolated $n=30$, combined $n=49$ ) and 228 underwent aortic valve surgery (isolated $\mathrm{n}=134$, combined $\mathrm{n}=94$ ).

RESULTS: The most frequent in-hospital complications were atrial arrhythmias, need for inotropic support for more than $48 \mathrm{~h}$, renal insufficiency, congestive heart failure, respiratory failure, and stroke or transient ischemic attack. The in-hospital mortality rate was $9.7 \%$ (30 of 307). Multivariate logistic regression identified the following clinical variables as predictors of in-hospital death: New York Heart Association functional class IV, diabetes, hypertension, renal insufficiency at presentation, rheumatic etiology and left ventricular ejection fraction of less than $45 \%$. Late mortality occurred in 45 of 277 patients $(16.2 \%)$, but there was a substantial improvement in the New York Heart Association functional class of the 232 long-term survivors (from $3.0 \pm 0.7$ to $1.7 \pm 0.6 ; \mathrm{P}<0.0001$ ).

CONCLUSIONS: Surgery seems to be an effective therapeutic option for selected symptomatic octogenarians with valve disease, associated with good long-term survival and an improved functional class. Operative mortality is related more to patients' preoperative clinical status and increased comorbidity than the type of surgery per se.

\section{Key Words: Octogenarians; Outcome; Valve surgery}

Olobal population aging and growing age-related incidence of $J_{\text {ischemic, degenerative and calcific valve disease have led to }}$ an increasing number of very elderly patients being referred for cardiac surgery (1-5). The results of recent studies suggest that open-heart surgery may be performed in elderly patients with acceptable rates of in-hospital morbidity and mortality, good long-term survival and quality of life, and only a slight increase in

\section{La chirurgie valvulaire chez les octogénaires : Les issues en milieu hospitalier et à long terme}

\begin{abstract}
HISTORIQUE : En raison du vieillissement de la population mondiale et de l'incidence plus élevée de maladies valvulaires ischémiques, dégénératives et calcifiantes, de plus en plus de patients âgés sont envoyés en consultation pour subir une opération valvulaire. Cependant, on n'a étudié à fond ni leurs facteurs de risque préopératoires, ni leurs issues en milieu hospitalier et à long terme.
\end{abstract}

MÉTHODOLOGIE : Trois cent sept patients consécutifs de plus de 80 ans ( $60 \%$ de femmes; âge moyen de $83 \pm 2,4$ ans) fréquentant trois grands centres italiens de cardiologie en prévision d'une opération valvulaire ont subi une évaluation : chirurgie valvulaire aortique seule $(\mathrm{n}=134)$ ou avec pontage aortocoronarien $(\mathrm{n}=94)$, chirurgie aortique $(n=3)$ ou chirurgie valvulaire mitrale $(n=26)$.

RÉSULTATS : Les complications les plus courantes en milieu hospitalier étaient l'arythmie auriculaire, le besoin d'un soutien inotrope pendant plus de 48 heures, une insuffisance rénale, une insuffisance cardiaque congestive, une insuffisance respiratoire et un accident vasculaire cérébral ou une ischémie transitoire. Le taux de mortalité en milieu hospitalier était de $9,7 \%$ (30 sur 307). La régression logistique multivariée a permis de repérer les variables cliniques prédictrices de décès en milieu hospitalier : classe fonctionnelle IV de la New York Heart Association, diabète, hypertension, insuffisance rénale à la présentation, étiologie rhumatismale et fraction d'éjection ventriculaire gauche inférieure à $45 \%$. On a recensé une mortalité tardive chez 45 des 277 patients (16,2\%), mais aussi une amélioration importante de la classe fonctionnelle de la New York Heart Association des 232 survivants à long terme (de $3,0 \pm 0,7$ à $1,7 \pm 0,6$; $\mathrm{p}<0,0001$ ).

CONCLUSIONS : L'opération semble une option thérapeutique efficace pour certains octogénaires symptomatiques atteints d'une maladie valvulaire, et elle s'associe à une bonne survie à long terme et à une amélioration de la classe fonctionnelle. La mortalité opératoire est davantage reliée à l'état clinique préopératoire et à un accroissement de la comorbidité qu'au type d'opération.

resource use compared with younger patients (4-7). However, the clinical outcomes of unselected octogenarians undergoing valve surgery have not been thoroughly investigated.

The aims of the present study were to evaluate the profiles of patients aged 80 years and older undergoing isolated or combined valve surgery, and to identify the clinical predictors of in-hospital (30-day) mortality.

${ }^{1}$ Institute of Clinical Physiology, National Research Council of Italy, Lecce Section, Lecce; 'San Giovanni di Dio e Ruggi D'Aragona Hospital, Salerno; ${ }^{3}$ Istituto Policlinico San Donato; ${ }^{4}$ Istituto Clinico Sant'Ambrogio, Milan; ${ }^{5}$ Cardiac Department, Azienda Sanitaria Locale Salerno 1,

Salerno, Italy; ${ }^{6}$ University of Michigan, Ann Arbor, Michigan; ${ }^{7}$ Duke Clinical Research Institute, Durham, North Carolina, USA

Correspondence: Dr Eduardo Bossone, Via Principe Amedeo, 36, 83023 Lauro, Italy. Telephone 39-081-8240067, fax 39-081-8240067, e-mail ebossone@hotmail.com

Received for publication August 3, 2005. Accepted March 28, 2006 


\section{TABLE 1}

Preoperative characteristics $(n=307)$

\begin{tabular}{|c|c|}
\hline Variable & \\
\hline Age, years (mean $\pm S D$ ) & $82.6 \pm 2.4$ \\
\hline Female sex, n (\%) & $184(59.9)$ \\
\hline \multicolumn{2}{|l|}{ Clinical symptoms and signs, $\mathrm{n}(\%)$} \\
\hline Shortness of breath & $305(99.3)$ \\
\hline Chest pain & $170(55.4)$ \\
\hline Paroxysmal nocturnal dyspnea & $76(24.8)$ \\
\hline Syncope & $115(37.5)$ \\
\hline Fever & $2(0.6)$ \\
\hline Peripheral edema & $107(34.8)$ \\
\hline Pulmonary embolism & $1(0.3)$ \\
\hline Pulmonary edema & $37(12.0)$ \\
\hline Acute myocardial infarction & $4(1.3)$ \\
\hline Unstable angina & $37(12.0)$ \\
\hline Congestive heart failure & $111(36.2)$ \\
\hline Cardiogenic shock & $3(1.0)$ \\
\hline Atrial fibrillation & $70(22.8)$ \\
\hline \multicolumn{2}{|l|}{ New York Heart Association functional class } \\
\hline II & $80(26.1)$ \\
\hline III & $139(45.3)$ \\
\hline IV & $88(28.7)$ \\
\hline \multicolumn{2}{|l|}{ Medical history, n (\%) } \\
\hline Diabetes mellitus & $62(20.2)$ \\
\hline Hypertension & $192(62.5)$ \\
\hline Hypercholesterolemia & $91(29.7)$ \\
\hline Smoking & $130(42.3)$ \\
\hline Previous myocardial infarction & $36(11.7)$ \\
\hline Coronary artery disease & $155(50.5)$ \\
\hline Cerebrovascular accident & $41(13.4)$ \\
\hline Peripheral vascular disease & $68(22.1)$ \\
\hline Chronic obstructive pulmonary disease & $103(33.5)$ \\
\hline Gastrointestinal bleeding & $32(10.4)$ \\
\hline Cancer & $8(2.6)$ \\
\hline Chronic renal insufficiency & $35(11.4)$ \\
\hline Liver failure & $2(0.6)$ \\
\hline \multicolumn{2}{|l|}{ Valve pathology, $\mathrm{n}(\%)$} \\
\hline Aortic stenosis & $235(76.5)$ \\
\hline Aortic regurgitation & $44(14.3)$ \\
\hline Mitral stenosis & $13(4.2)$ \\
\hline Mitral regurgitation & $74(24.1)$ \\
\hline Tricuspid regurgitation & $10(3.3)$ \\
\hline \multicolumn{2}{|l|}{ Previous cardiac surgery, n (\%) } \\
\hline Coronary artery bypass & $4(1.3)$ \\
\hline Percutaneous transluminal coronary angioplasty & $1(0.3)$ \\
\hline Aortic valve & $2(0.6)$ \\
\hline Mitral valve & $2(0.6)$ \\
\hline Mitral valvuloplasty & $5(1.6)$ \\
\hline Tricuspid valvuloplasty & $1(0.3)$ \\
\hline Previous vascular surgery, $\mathrm{n}(\%)$ & $10(3.3)$ \\
\hline Carotid & $3(1.0)$ \\
\hline Aortic & $6(2.0)$ \\
\hline Peripheral & $4(1.3)$ \\
\hline
\end{tabular}

\section{METHODS}

Between January 1994 and March 2001, 307 consecutive patients aged 80 to 94 years $(59.9 \%$ female; mean age \pm SD $82.6 \pm 2.4$ years) underwent isolated $(n=164,53.4 \%)$ or combined $(n=143,46.6 \%)$ cardiac valve surgery at three major cardiac surgery centres in Italy. All the procedures were carried out via a standard median sternotomy with cardiopulmonary bypass and at least mild systemic hypothermia. Cardiac arrest was achieved by means of cold crystalloid or blood cardioplegia. The selection of the type of valve prosthesis was left to the discretion of the operating surgeon. At each site, prespecified data were collected both retrospectively by chart review and prospectively by direct interview of patients at the time of admission. The standard data entry form included preoperative, demographic and clinical information, operative characteristics, as well as any postoperative in-hospital clinical events, including mortality, using standard American College of Cardiology/American Heart Association definitions (8). The completed forms were forwarded to the coordinating centre (Institute of Clinical Physiology, National Research Council of Italy, Lecce, Italy), where the data were manually entered into an Excel database (Microsoft Corp, USA).

Late follow-up information concerning mortality and functional status (New York Heart Association [NYHA] functional class) was obtained by means of dedicated follow-up telephone interviews with the patients and/or their relatives using a standardized questionnaire. In the case of death, the patient's physician, or the appropriate hospital records department or City Hall office, was contacted to document the event. The follow-up was 100\% complete. All patients gave their informed consent; no patients refused to participate.

\section{Statistics}

The patients' baseline characteristics, operative characteristics and postoperative results were summarized as frequencies and percentages for categorical variables, and mean values \pm SD for continuous variables. The associations with death among the nominal variables were compared using the $\chi^{2}$ test or Fisher's exact test (when the cell count was less than five). The continuous variables were compared using a Student's $t$ test or the Wilcoxon-Mann-Whitney test, as appropriate. Iterative logistic regression modelling was used to derive independent associations with in-hospital mortality. Diagnostic routines (the Hosmer-Lemeshow test for lack of fit and the likelihood ratio test) were used for the final model selection, and the area under the receiver operating characteristic curve was calculated to assess model discrimination. The survival estimates of patients undergoing different types of surgery were determined using the Kaplan-Meier method. All analyses were performed using SAS software (version 8.2, SAS Institute, USA).

\section{RESULTS}

The patients' demographic and preoperative clinical characteristics are shown in Table 1. The most frequent clinical symptoms at presentation were shortness of breath $(99.3 \%)$ and chest pain $(55.4 \%)$; the past medical histories mainly included hypertension (62.5\%) and coronary artery disease $(50.5 \%)$ (Table 1$)$. The majority of patients underwent isolated or combined aortic valve surgery $(74.3 \%)$ (Table 2$)$.

The most frequent in-hospital complications were atrial arrhythmias (49.8\%) and a need for inotropic support for more than $48 \mathrm{~h}(37.1 \%)$ (Table 3$)$. Overall in-hospital mortality was $9.7 \%$, with the highest rate among patients undergoing combined mitral valve surgery (MVSc) (20.4\%; Table 4 and Figure 1). The multivariate predictors of in-hospital death included NYHA functional class IV, diabetes, hypertension, renal insufficiency at presentation, rheumatic etiology and left ventricular ejection fraction of less than 45\% (Table 5). 
TABLE 2

Operative characteristics

\begin{tabular}{lc}
\hline Variable & \\
\hline Operative priority, $\mathrm{n}(\%)$ & $252(82.1)$ \\
Elective & $49(16.0)$ \\
Urgent & $6(1.9)$ \\
Emergent & $91.2 \pm 33.7$ \\
Cardiopulmonary bypass time, min (mean \pm SD) & $69.3 \pm 23.5$ \\
Cross-clamp time, min (mean \pm SD) & $79 / 307(25.7)$ \\
Mitral valve surgery, n/total (\%) & $35 / 79(44.3)$ \\
Repair & $44 / 79(55.7)$ \\
Replacement & \\
Valve prosthesis & $23 / 44(52.3)$ \\
$\quad$ Biological & $21 / 44(47.7)$ \\
$\quad$ Mechanical & $30 / 79(38.0)$ \\
Isolated & $49 / 79(62.0)$ \\
Combined with & $29 / 49(59.2)$ \\
Coronary artery bypass graft surgery & $26 / 49(53.1)$ \\
Aortic valve replacement & $10 / 49(20.4)$ \\
Tricuspid valve repair & $228 / 307(74.3)$ \\
Aortic valve surgery, n/total (\%) & \\
Valve prosthesis & $109 / 228(47.8)$ \\
Biological & $43 / 228(18.8)$ \\
Stentless & $76 / 228(33.3)$ \\
Mechanical & $134 / 228(58.8)$ \\
Isolated & $94 / 228(41.2)$ \\
Combined with & $91 / 94(96.8)$ \\
Aortic root surgery & $3 / 94(3.2)$ \\
\hline &
\end{tabular}

At late follow-up (42 \pm 30 months; range one to 134 months), there were 45 additional deaths, with the highest mortality rate among patients undergoing MVSc (20.5\%) or combined aortic valve surgery (AVSc) (20.0\%; Table 4 and Figure 2). Among the 232 long-term survivors, the NYHA functional class improved from $3.0 \pm 0.7$ preoperatively to $1.7 \pm 0.6$ postoperatively; all types of surgery significantly improved NYHA functional class $(\mathrm{P}<0.0001$; Table 6$)$.

\section{DISCUSSION}

The increase in average age in the western world has led to a significant increase in the number of elderly patients being referred for cardiac surgery (1-5). Although there are many data concerning open-heart surgery (particularly $\mathrm{CABG}$ ) in elderly patients, much less is known about early and late mortality rates, nonfatal adverse events, functional status and resource use in octogenarians undergoing valve surgery $(5,9-14)$. Ours was one of the largest European studies of a wide range of isolated or combined complex valve surgical interventions and included postoperative complications, late functional status, and the risk factors associated with early and late death.

It is not surprising that perioperative morbidity, mortality and complications were considerable, and led to a greater use of resources. Although we did not evaluate hospital costs, previous investigators have reported higher costs for older patients than younger patients, and attributed them to longer average periods of hospitalization and more complications $(4,7,15)$. Notwithstanding the higher perioperative morbidity rate and greater costs, the overall operative mortality rate was not
TABLE 3

Postoperative early results

\begin{tabular}{lc}
\hline Variable & \\
\hline Hospital stay, days (mean $\pm \mathrm{SD}$ ) & $14.9 \pm 10.5$ \\
Intensive care unit stay, days (mean $\pm \mathrm{SD}$ ) & $5.4 \pm 8.5$ \\
In-hospital complications, $\mathrm{n}(\%)$ & \\
Congestive heart failure & $69(22.48)$ \\
Shock & $43(14.01)$ \\
Acute myocardial infarction & $9(2.93)$ \\
Cardiac arrest & $10(3.26)$ \\
Bleeding & $49(15.96)$ \\
Atrial arrhythmia & $153(49.84)$ \\
Pneumonia & $23(7.49)$ \\
Mediastinitis & $1(0.33)$ \\
Ventricular arrhythmia & $55(17.92)$ \\
Renal failure & $87(28.34)$ \\
Respiratory failure & $68(22.15)$ \\
Hepatic failure & $12(3.91)$ \\
Inotropic support $>48 \mathrm{~h}$ & $114(37.13)$ \\
Re-exploration & $13(4.25)$ \\
Intra-aortic balloon pump & $7(2.28)$ \\
Sepsis & $8(2.61)$ \\
Wound infection & $3(0.98)$ \\
Cerebrovascular accident & $8(2.61)$ \\
Transient ischemic attack & $11(3.58)$ \\
Permanent pacemaker & $11(3.58)$ \\
\hline
\end{tabular}

TABLE 4

In-hospital and late mortality by type of surgery

\begin{tabular}{lcr}
\hline Type of surgery & $\begin{array}{c}\text { In-hospital } \\
\text { mortality, } \\
\text { n/total (\%) }\end{array}$ & $\begin{array}{c}\text { Late } \\
\text { mortality, } \\
\text { n/total (\%) }\end{array}$ \\
\hline Total & $30 / 307(9.7)$ & $45 / 277(16.2)$ \\
Isolated aortic valve surgery & $7 / 134(5.2)$ & $17 / 127(13.3)$ \\
Combined aortic valve surgery & $9 / 94(9.6)$ & $17 / 85(20.0)$ \\
Isolated mitral valve surgery & $4 / 30(13.3)$ & $3 / 26(11.5)$ \\
Combined mitral valve surgery & $10 / 49(20.4)$ & $8 / 39(20.5)$ \\
\hline
\end{tabular}

prohibitive $(9.8 \%$, ranging from $5.2 \%$ for isolated aortic valve surgery to $20.4 \%$ for MVSc and AVSc) considering the known high risk of such procedures in the very elderly and that late mortality was only $16.2 \%$ (ranging from $13.3 \%$ for isolated aortic valve surgery to $20.5 \%$ for MVSc); furthermore, the functional status of the long-term survivors significantly improved.

Isolated mitral valve surgery, MVSc and AVSc led to the highest short- and long-term mortality rates, but the type of surgery was not an independent predictor of operative mortality after adjusting for confounding factors, and NYHA functional class improved regardless of the type of surgery, which is in line with the findings of other investigators $(6,16,17)$. Our data actually suggest that preoperative clinical status is the major determinant of in-hospital death. The presence of comorbid diseases plays an important role in determining operative risk and we identified NYHA functional class IV, diabetes, hypertension, renal insufficiency, rheumatic etiology and left ventricular ejection fraction of less than $45 \%$ as independent risk factors for early death in our high-risk cohort, as did others (18). These data may be helpful in assessing preoperative clinical risk, thus allowing physicians, patients and 
TABLE 6

Preoperative versus late follow-up New York Heart Association (NYHA) functional class

\begin{tabular}{|c|c|c|c|c|}
\hline Type of surgery & $\begin{array}{c}\text { Preoperative NYHA } \\
\text { functional class }\end{array}$ & $\begin{array}{c}\text { Late follow-up NYHA } \\
\text { functional class }\end{array}$ & $\begin{array}{l}\text { Change in NYHA } \\
\text { functional class }\end{array}$ & $\mathbf{P}$ \\
\hline Isolated aortic valve surgery & $2.8 \pm 0.65$ & $1.5 \pm 0.62$ & $1.2 \pm 0.82$ & $<0.0001$ \\
\hline Combined aortic valve surgery & $3.1 \pm 0.76$ & $1.7 \pm 0.59$ & $1.4 \pm 0.84$ & $<0.0001$ \\
\hline Isolated mitral valve surgery & $3.2 \pm 0.71$ & $1.9 \pm 0.37$ & $1.1 \pm 0.72$ & $<0.0001$ \\
\hline Combined mitral valve surgery & $3.4 \pm 0.71$ & $1.9 \pm 0.74$ & $1.5 \pm 1.1$ & $<0.0001$ \\
\hline
\end{tabular}

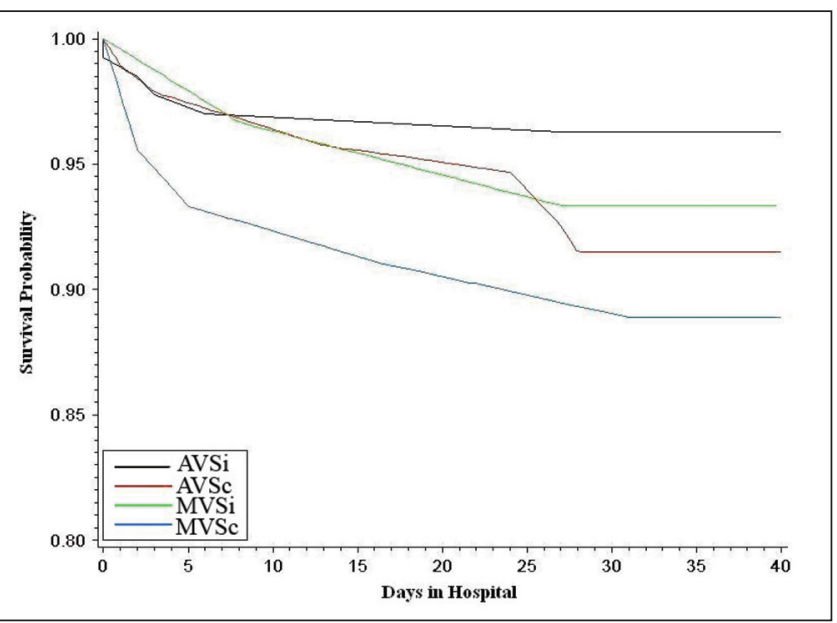

Figure 1) Kaplan-Meier method in-hospital survival curves for patients with different surgery types. Log rank test $P<0.46$. AVSc Combined aortic valve surgery; AVSi Isolated aortic valve surgery; MVSc Combined mitral valve surgery; MVSi Isolated mitral valve surgery

TABLE 5

Clinical predictors of in-hospital mortality in multivariate logistic regression analysis

\begin{tabular}{lllc}
\hline Variable & \multicolumn{3}{c}{$\mathbf{R R}$} \\
NYHA functional class IV & $\mathbf{R}$ & $\mathbf{9 5 \%} \mathbf{~ C l}$ & $\mathbf{P}$ \\
\hline Diabetes & 5.2 & $1.9-14.0$ & 0.001 \\
Hypertension & 2.8 & $1.1-7.1$ & 0.027 \\
Renal insufficiency & 3.7 & $1.2-11.0$ & 0.025 \\
Rheumatic etiology & 3.4 & $1.2-9.4$ & 0.022 \\
Left ventricular ejection fraction $<45 \%$ & 6.2 & $1.1-12.9$ & 0.030 \\
\hline
\end{tabular}

NYHA New York Heart Association

relatives to consider the risk and potential benefits of valvular surgery more rationally, although they should not be used to deny high-risk patients valve surgery because their quality of life and outcomes would be dismal without it.

Although we did not evaluate other outcomes, such as quality of life, previous studies $(6,16-19)$ have shown that acceptable mortality and improved functional status in octogenarians also lead to a better quality of life. For example, Sundt et al (6) reported an excellent long-term functional outcome (NYHA functional class) and an improved quality of life (Short Form-36) in a series of 65 patients older than 80 years of age undergoing aortic valve replacement alone or in combination with other procedures $(6,20)$.

\section{CONCLUSIONS AND FUTURE DIRECTIONS}

It is reasonable to conclude that, for selected symptomatic octogenarians with advanced valve disease, surgery is an effective

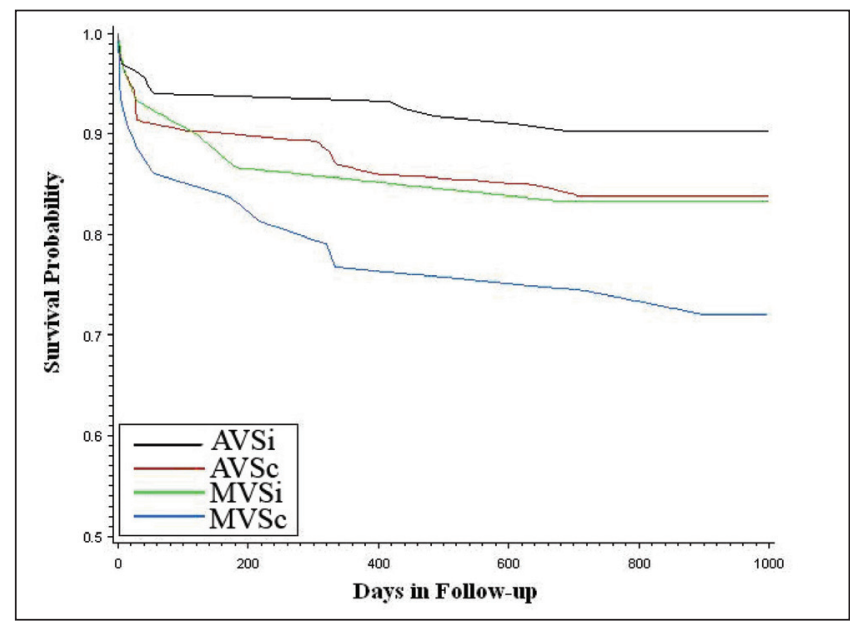

Figure 2) Kaplan-Meier method follow-up survival curves for patients with different surgery types. Log rank test $P<0.017$. AVSc Combined aortic valve surgery; AVSi Isolated aortic valve surgery; MVSc Combined mitral valve surgery; MVSi Isolated mitral valve surgery

therapeutic option that is associated with good long-term survival and an improved NYHA functional class. In addition, operative mortality for these patients is more related to increased comorbidity and poor left ventricular function than to the type of surgery per se. Any socioeconomic 'justification' would require a more detailed assessment of the improvement in the quality of life, and the costs of the procedure and hospital care (21). Identifying age-matched cohorts with and without valvular heart disease may better clarify the extent to which long-term mortality trends reflect an outcome attributable to surgery, valvular heart disease or advanced age (22).

\section{REFERENCES}

1. Spencer G. US Bureau of the Census: Projections of the population of the United States by age, sex and race: 1988-2080. Washington: US Government Printing Office, 1989. Current Population Reports. Series P-25, No 1018.

2. US Senate Special Committee on Aging and the US Administration on Aging. Aging America. Trends and Projections 1991. Washington: US Government Printing Office, 1991.

3. American Heart Association. 1993 Heart and Stroke Facts Statistics. Ref 29;WG16;H35;1993:1-16.

4. Peterson ED, Cowper PA, Jollis JC, et al. Outcomes of coronary artery bypass graft surgery in 24,461 patients aged 80 years or older. Circulation 1995;92(Suppl):II85-91.

5. Alexander KP, Anstrom KJ, Muhlbaier LH, et al. Outcomes of cardiac surgery in patients age > or $=80$ years: Results from the National Cardiovascular Network. J Am Coll Cardiol 2000;35:731-8

6. Sundt TM, Bailey MS, Moon MR, et al. Quality of life after aortic valve replacement at the age of $>80$ years. Circulation 2000;102(Suppl 3):III70-4.

7. Avery GJ II, Ley SJ, Hill D, Hershon JJ, Dick SE. Cardiac surgery in the octogenarian: Evaluation of risk, cost, and outcome. Ann Thorac Surg 2001;71:591-6. 
8. Eagle KA, Guyton RA, Davidoff R, et al. ACC/AHA guidelines for coronary artery bypass graft surgery: Executive summary and recommendations: A report of the American College of Cardiology/American Heart Association Task Force on Practice Guidelines (Committee to revise the 1991 guidelines for coronary artery bypass graft surgery). Circulation 1999;100:1464-80.

9. Edmunds LH Jr, Stephenson LW, Edie RN, Ratcliffe MB. Openheart surgery in octogenarians. N Engl J Med 1988;319:131-6.

10. Bashour TT, Hanna ES, Myler RK, et al. Cardiac surgery in patients over the age of 80 years. Clin Cardiol 1990;13:267-70.

11. Deiwick M, Tandler R, Mollhoff T, et al. Heart surgery in patients aged eighty years and above: Determinants of morbidity and mortality. Thorac Cardiovasc Surg 1997;45:119-26.

12. Craver JM, Puskas JD, Weintraub WW, et al. 601 octogenarians undergoing cardiac surgery: Outcome and comparison with younger age groups. Ann Thorac Surg 1999;67:1104-10.

13. Ralph-Edwards AC, Robinson AG, Gordon RS, Ivanov J. Valve surgery in octogenarians. Can J Cardiol 1999;15:1113-9.

14. Kolh P, Kerzmann A, Lahaye L, Gerard P, Limet R. Cardiac surgery in octogenarians; peri-operative outcome and long-term results. Eur Heart J 2001;22:1235-43.

15. Engoren M, Arslanian-Engoren C, Steckel D, Neihardt J, Fenn-Buderer N. Cost, outcome, and functional status in octogenarians and septuagenarians after cardiac surgery. Chest 2002;122:1309-15.

16. Diegeler A, Autschbach R, Falk V, et al. Open heart surgery in the octogenarians - a study on long-term survival and quality of life. Thorac Cardiovasc Surg 1995;43:265-70.

17. Kumar P, Zehr KJ, Chang A, Cameron DE, Baumgartener WA. Quality of life in octogenarians after open heart surgery. Chest 1995;108:919-26.

18. Mehta RH, Eagle KA, Coombs LP, et al; Society of Thoracic Surgeons National Cardiac Registry. Influence of age on outcomes in patients undergoing mitral valve replacement. Ann Thorac Surg 2002;74:1459-67.

19. Khan JH, McElhinney DB, Hall TS, Merrick SH. Cardiac valve surgery in octogenarians: Improving quality of life and functional status. Arch Surg 1998;133:887-93.

20. Bungay KM, Ware JE. Measuring and Monitoring Health-Related Quality of Life: Current Concepts. Kalamazoo: The Upjohn Company, 1993.

21. Rady MY, Johnson DJ. Cardiac surgery for octogenarians: Is it an informed consent decision? Am Heart J 2004;147:347-53.

22. Stoica S, Cafferty F, Kitcat J, et al. Octogenarians undergoing cardiac surgery outlive their peers - a case for early referral. Heart 2005;92:503-6. 